\title{
NEUROENDOCRINOLOGY OF FISH METAMORPHOSIS AND PUBERTY: EVOLUTIONARY AND ECOPHYSIOLOGICAL PERSPECTIVES
}

Sylvie Dufour

UMR 5178 CNRS Biology of Marine Organisms and Ecosystems, National Museum of Natural History (MNHN), National Center for Scientific Research (CNRS), University Pierre \& Marie Curie (Paris VI), Paris, France., dufour@mnhn.fr

Karine Rousseau UMR 5178 CNRS Biology of Marine Organisms and Ecosystems, National Museum of Natural History (MNHN), National Center for Scientific Research (CNRS), University Pierre \& Marie Curie (Paris VI), Paris, France.

Follow this and additional works at: https://jmstt.ntou.edu.tw/journal

Part of the Aquaculture and Fisheries Commons

\section{Recommended Citation}

Dufour, Sylvie and Rousseau, Karine (2007) "NEUROENDOCRINOLOGY OF FISH METAMORPHOSIS AND PUBERTY:

EVOLUTIONARY AND ECOPHYSIOLOGICAL PERSPECTIVES," Journal of Marine Science and Technology. Vol. 15: Iss.

5, Article 6.

DOI: $10.51400 / 2709-6998.2058$

Available at: https://jmstt.ntou.edu.tw/journal/vol15/iss5/6

This Research Article is brought to you for free and open access by Journal of Marine Science and Technology. It has been accepted for inclusion in Journal of Marine Science and Technology by an authorized editor of Journal of Marine Science and Technology. 


\title{
NEUROENDOCRINOLOGY OF FISH METAMORPHOSIS AND PUBERTY: EVOLUTIONARY AND ECOPHYSIOLOGICAL PERSPECTIVES
}

\author{
Sylvie Dufour* and Karine Rousseau*
}

Key words: puberty, metamorphosis, vertebrates, teleosts, neuroendocrinology, thyroid hormones, steroids, silvering, smoltification,

\section{ABSTRACT}

Metamorphosis and puberty are two major events of the postembryonic development in Vertebrates. Based on some examples from fish species, we review the definition, role and regulation of these events, analyze their common and different features, as well as their impact on the evolution and diversity of life cycles.

The term of puberty, firstly defined in humans, has been subsequently extended to the first acquisition of the capacity to reproduce in all mammalian and non-mammalian vertebrates as well as in invertebrates. By definition, puberty occurs only once in the life cycle. However, some similarities may be found with other events, such as annual re-activation of the reproductive function in seasonal breeders or sex-change in adults, as observed in some fish species.

Metamorphosis allows the transition from one developmental stage in a specific environment to the next stage in a different environment, and includes a migration between the two habitats. Metamorphosis corresponds to drastic changes in body shape, physiology and behavior, and, unlike puberty, is encountered only in some phyla/species. In Vertebrates, the most described metamorphosis is the transformation in Amphibians of the aquatic larva (tadpole) into the terrestrial juvenile. Larval metamorphosis is also encountered in some other Vertebrates, such as lampreys and some teleosts (Elopomorphes and Pleuronectiformes). Less drastic morphological, physiological and behavioral changes occur in juveniles of some migratory teleosts. This is the case of smoltification in salmons and silvering in eels, which are referred to as "secondary metamorphoses".

Investigations on the regulation of puberty and metamorphoses in Vertebrates reveal the crucial roles of the neuroendocrine axes. In all Vertebrates, puberty is triggered by the activation of the gonadotropic axis, constituted of brain neuropeptide (gonadotropin-releasing hormone, GnRH), pituitary glycoprotein hormones (gonadotropins: luteinizing hormone, $\mathrm{LH}$ and follicle stimulating hormone, FSH) and gonadal steroids. Sex steroids induce the morpho-physiological and behavioral transformations characteristic of puberty.

Metamorphosis in Amphibians is triggered by the thyrotropic axis, constituted of brain neuropeptide corticotropin-releasing hor-

Author for Correspondence: Sylvie Dufour.

E-mail:dufour@mnhn.fr.

*UMR 5178 CNRS Biology of Marine Organisms and Ecosystems, National Museum of Natural History (MNHN), National Center for Scientific Research (CNRS), University Pierre \& Marie Curie (Paris VI), Paris, France. mone $(\mathrm{CRH})$, instead of thyrotropin-releasing hormone, (TRH), pituitary glycoprotein hormone (thyrotropin, $\mathrm{TSH}$ ) and thyroid hormones (TH: thyroxine, T4 and triiodothyronine, T3), which play a key-role in the induction of morpho-physiological and behavioral changes. A similar control is suggested for larval metamorphosis in teleosts.

Studies on smoltification also indicate an important role of thyroid hormones in secondary metamorphoses in teleosts, even though other hormones such as growth hormone $(\mathrm{GH})$ and corticosteroids may be of prime importance. In contrast, recent investigations in the eel reveal that the gonadotropic axis, and ultimately sex steroids would be the major triggering control of silvering. The similarities of the morpho-physiological and behavioral changes between the two species indicate remarkable evolutionary convergences in the morphogenetic roles and target tissues of TH and sex steroids for the induction of secondary metamorphoses. In all cases, the possible synergistic role of cortisol is highlighted.

Comparison of puberty and metamorphosis may also favor our understanding of the internal and environmental triggering signals of these postembryonic developmental events. In teleosts, the large plasticity in the occurrence and timing of metamorphosis and puberty, which contributes to the high diversity of fish life cycles, may provide new and relevant models to such investigations.

\section{INTRODUCTION: DEFINITION OF PUBERTY AND METAMORPHOSIS}

Metamorphosis and puberty are two major events of the postembryonic development.

\section{Puberty and related events}

The term of puberty, firstly defined in humans, has been subsequently extended to the first acquisition of the capacity to reproduce in all mammalian and nonmammalian vertebrates as well as in invertebrates.

By definition, puberty occurs only once in the life cycle after a certain period of juvenile growth phase. However, some similarities may be found with other physiological events, such as the annual re-activation of the reproductive function, as observed in seasonal breeders $[43,143]$. Furthermore, in the remarkable case of fish species that are able to change sex during their life cycle [4], the new ability to reproduce as a member of the opposite sex could also be considered as a "second puberty". 


\section{Metamorphosis and related events}

Metamorphosis allows the transition from one developmental stage in a specific environment (ecophase 1 in habitat 1) to the next stage in a quite different environment (ecophase 2 in habitat 2), and normally includes the occurrence of a migratory phase between the two habitats. Metamorphosis corresponds to drastic changes in body shape, physiology and behavior, and, unlike puberty, is encountered only in some phyla/ species. In Vertebrates, the classical and most described model for metamorphosis is the one of the Anuran Amphibians, which transforms the aquatic larva (tadpole) into a terrestrial, adult-like shaped, juvenile. Larval metamorphosis, also called "primary metamorphosis" is encountered in some other vertebrates, such as in lampreys (Agnathans) and teleosts (Elopomorphes, Pleuronectiformes) [157].

Other developmental events, which also encompass morphological, physiological and behavioral (migratory) changes, even though less drastic than for the larval metamorphosis, are encountered in some migratory teleosts [116]. This is the case of smoltification in salmons and silvering in eels. These developmental events occur after some period of juvenile phase and prepare the fish to the transition between the continental habitat and the oceanic one. They are traditionally referred to as "secondary metamorphoses".

Birth in mammals or hatching in oviparous Vertebrates, which are abrupt transitions from egg/ maternal to outside environment, may also present some common features with metamorphoses.

Investigations on the regulation of puberty and metamorphoses in Vertebrates reveal the key roles of the brain-pituitary neuroendocrine axes.

\section{NEUROENDOCRINE CONTROL OF PUBERTY}

\section{Neuroendocrine control of puberty in mammals}

Puberty in mammals is clearly characterized by an activation of the gonadotropic axis $[31,127]$. This neuroendocrine axis is constituted of a brain neuropeptide, the gonadotropin-releasing hormone $(\mathrm{GnRH})$, which stimulate synthesis and release of pituitary glycoprotein hormones, the gonadotropins, luteinizing hormone (LH) and follicle stimulating hormone (FSH), which act on the gonads to activate gametogenesis and steroidogenesis. Sex steroids (androgens and estrogens) act as potent morphogenic hormones on the peripheral target tissues, inducing various morpho-physiological and behavioral changes, characteristics of the puberty (secondary sexual characters) $[115,127]$. In addition, sex steroids exert positive and negative feedbacks on the brain-pituitary axis, allowing a regulatory cross talk between central and peripheral components of the gonadotropic axis.

The pubertal activation of the gonadotropic axis occurs after a certain duration of juvenile phase (also called "infancy"), which allows the organism to reach certain age, size, energy stores sufficient enough to ensure the success of reproduction [7, 38, 39, 60, 68]. The duration of this phase depends on genetic, internal and environmental factors. It can be short (for instance in the mice) or long (as in humans) depending on the life cycle strategies. In seasonal breeders (for instance in sheep), a seasonal reactivation of the gonadotropic axis occurs every year after puberty and presents many common features with puberty itself [143]. Thus, alternate phases of inhibition and re-activation of the gonadotropic axis are at the basis of the annual cycles of reproduction.

Recent studies showed that a peptide named kisspeptin (or metastin), product of the Kiss-1 gene, played a major role in the onset of puberty in mammals $[12,95,122,130]$. In 2003, three groups described the effects of knock-out [40, 123] and mutation [21] of GPR54, which is kisspeptin receptor. They observed that when GPR54 is absent or mutated, mice or humans were unable to undergo puberty, because of small gonads, and low concentrations of sexual steroids and gonadotropins. In 2005, Messager and collaborators showed that in mice lacking GPR54, the anatomy and localisation of GnRH neurons, as well as GnRH concentration in the brain, remained unchanged. These results suggested that there was no problem in GnRH synthesis in these mice, but that GnRH release was blocked. Hypothalamic expression of kisspeptin and its receptor increase dramatically at puberty and is modulated by sex steroids (rat: [97]; mouse: [130]; rhesus monkey: [124]). Recently, studies demonstrated that GPR54 receptor was expressed within GnRH neurons in mammals (mouse: [86]; ovins: [108]). Kisspeptin injections to different animal models can induce the release of $\mathrm{GnRH}$ release, as well as FSH and LH, whereas administration of antibodies against kisspeptin block reproductive function, even when puberty has been initiated [25, 44, 82, 144]. Concomitant injection of kisspeptin and GnRH antagonist blocks the stimulatory effect of the peptide on FSH and LH release [124], and kisspeptin has no direct effect in vitro on FSH and $\mathrm{LH}$ release [144]. All these data show that at puberty, kisppeptin, which brain expression is increased, acts via GPR54 receptor directly on GnRH neurons in order to induced GnRH release which then stimulates the pituitary production of LH and FSH . In a seasonal model, the Syrian hamster, it was shown that melatonin impacted on Kiss1 expression to control reproduction and that Kiss-1 
expression was significantly higher in hamsters kept in long-day as compared to short-day [111]. These data suggest that photoperiod, via melatonin, modulates Kiss1 neurons to drive the reproductive axis in seasonal breeders [111].

\section{Neuroendocrine control of puberty in teleosts}

This scheme (GnRH/LH-FSH/sex steroids) is largely conserved among Vertebrates [101], even though additional controls may occur such as the dopaminergic inhibition of gonadotropin production in some teleosts $[29,104]$. Indeed, pioneer works from Peter and collaborators on goldfish using hypothalamic lesions demonstrated the existence of a GRIF (gonadotropin release-inhibiting factor) [105-107] Subsequent studies using agonists or antagonists in vivo $[9,10]$, primary culture of pituitary cells in vitro [11] and immunocytochemistry [64-66] provided evidences that GRIF was dopamine (DA). An inhibitory role of DA on the control of LH has been evidenced in many adult teleosts at the time of ovulation and spermiation (catfish: [16, 145]; coho salmon: [146]; rainbow trout: [76, 118]; common carp: [75]; tilapia: [154]). However, DA does not play an inhibitory role in all adult teleosts (Atlantic croaker: [13]; gilthead seabream: [161]).

Concerning the early stages of gametogenesis and the control of puberty, up to now, the possible involvement of DA has only been studied in a few species. In juvenile striped bass [55] and red seabream [72], data refuted a role for DA in the prepubertal control of gonadotropins, as GnRH alone was able to trigger precocious puberty. In contrast in European eel, only a triple treatment with testosterone, GnRH agonist and pimozide (DA-receptor antagonist) could induce increases in LH synthesis and release, indicating that removal of DA inhibition is required in prepubertal eel for triggering GnRH-stimulated LH synthesis and release [148]. A recent study in the grey mullet has demonstrated that D2 type receptor expressions in the brain and in the pituitary were high at the early and intermediate stages of puberty [98], when inhibition of the reproductive function by DA is particularly pronounced [1].

In male tilapia, GPR54 mRNA was found to be colocalized within all three GnRH neuron subtypes [103], and the number of neurons expressing GPR54, as well as the level of GPR54 expression, increased with gonadal maturation [103]. In cobia Rachycentron canadum, concomitant expression patterns of GPR54 and GnRH mRNAs were reported during different stages of larval and juvenile developments [92]. Moreover, an increase in GPR54 was observed during early puberty [92], as in pubertal rats [97] and rhesus monkey [124]. Similarly, in female grey mullet (Mugil cephalus), significantly high levels of GPR54 mRNAs were demonstrated in brain at the early stage of puberty that subsequently decreased as puberty advanced [98].

\section{NEUROENDOCRINE CONTROL OF LARVAL METAMORPHOSIS}

\section{Neuroendocrine control of amphibian metamorphosis}

Early data on the regulation of metamorphosis came from Amphibians and demonstrated the key-role of a surge in thyroid hormones (TH: thyroxine, $\mathrm{T} 4$ and triiodothyronine, T3), in the induction of the many morpho-physiological and behavioral changes characteristics of the larval metamorphosis. The role of the thyroid gland in the control of larval metamorphosis was first demonstrated by Gudernatsch in 1912 after he observed the acceleration of the tadpole transformation into frogs when feeding them with thyroid gland extracts. Inversely, Allen [2] was able to completely prevent metamorphosis by thyroidectomy. As the thyrotropic axis is activated, a series of sequential morphological transformations occur. An early change is the growth and differential of the limbs, which in the absence of hormone, still form but will not progress beyond the bud stage. The final morphological change, tail resorption, occurs when the level of TH is highest at the climax of metamorphosis [67, 142].

Thyrotropin (TSH), a pituitary glycoprotein hormone, belonging to the same family as gonadotropins, controls the production of TH in Amphibians [80], as classically shown in mammals [85]. Early studies of hypophysectomy and immunization demonstrated that TSH played a central role in amphibian metamorphosis [26, 32]. Indeed, Dodd and Dodd [26] showed that the negative effect of hypophysectomy prior to metamorphosis could be reversed by treatment with mammalian TSH. Furthermore, passive immunization of tadpoles with an antiserum to bovine TSH prevented spontaneous metamorphosis [32]. Morphological and biochemical changes observed during metamorphosis, such as complete regression of tail and gills, de novo formation of bone, visual pigment transformation or functional differentiation of liver, can be induced by TH [126, 141]. In contrast to the situation in mammals in which the brain peptide discovered for its stimulatory control on TSH is TRH (for Thyrotropin Releasing Hormone) [93], the brain neurohormone responsible for the activation of TSH production during amphibian metamorphosis, is corticotropin-releasing hormone $(\mathrm{CRH})$ and not TRH [23]. In fact, in amphibians, the production and release of TSH by the pituitary appears to be regulated by different neuropeptides according to the life 
stage. Indeed, in premetamorphic amphibians, stimulation of the pituitary-thyroid axis is only responsive to $\mathrm{CRH}-$ like peptides and unresponsive to all other neurohormones tested, including TRH [22,24]. Thus, CRH is the thyrotropin-releasing factor during the induction of metamorphosis in tadpoles, and the stimulatory action of TRH on TSH secretion develops after metamorphic climax [23, 142].

Although TH is the only obligatory signal for the initiation and completion of amphibian metamorphosis, other hormones can modulate the onset and progression of metamorphosis [142]. These include glucocorticoids and prolactin (PRL), which can accelerate and prevents TH-induced metamorphosis, respectively [70, 140, 151]. In Amphibians, the importance of CRH in metamorphosis is reinforced by its traditional and evolutionary conserved role in the corticotropic axis itself (activation of pituitary corticotropin (ACTH) and adrenal cortisol). Indeed, cortisol has been shown to act in synergy with $\mathrm{TH}$ for the induction of various metamorphosis-related morphogenetic changes.

\section{Neuroendocrine control of larval metamorphosis in lamprey}

Lampreys, which are extant representatives of some of the oldest known vertebrates, the jawless fish or Agnatha [35, 36], also show a larval metamorphosis, first described by Muller [94], in their life cycle [158]. During this metamorphosis, there are major changes in external and internal features, and among them: final development of the eye; total regression of the larval kidney, replaced by an adult one; transformation of the epithelium in the intestine, gills and endostyle; development of teeth and tongue needed for adult feeding $[156,157]$.

Opposite to the situation observed in amphibians, larval (ammocoete) metamorphosis in lampreys is characterized by a sharp drop in T4 and T3 plasma levels (sea lamprey, Petromyzon marinus: [152, 159]; sea lamprey and Lampetra lamottenii: [77]; southern hemisphere lamprey, Geotria australis: [74], whereas concentrations of thyroid hormones during their larval life are among the highest recorded in any vertebrate [77].

Accordingly, immersion of ammocoetes in potassium perchlorate $\left(\mathrm{KClO}_{4}\right)$ (which inhibits iodide uptake and TH synthesis by the thyroid: [8] resulted in precocious metamorphosis (Lampetra planeri: [55, 134]; Lampetra reissneri: [136]). Moreover, both T4 and T3 treatment can block $\mathrm{KClO}_{4}$-induced metamorphosis [81, 158] and T3 treatment can inhibit spontaneous metamorphosis [160]. However, the use of propythiouracil (PTU), another inhibitor of TH synthesis, was unable to induce metamorphosis in the southern hemisphere lamprey, despite the decline in serum levels of $\mathrm{T} 4$ and T3 [74]. In addition, artificial maintenance of serum concentrations of thyroid hormones in immediately premetamorphic lampreys did not block metamorphosis in all individuals [158].

Studies on deiodinases and $\mathrm{TH}$ receptors gave interesting data, which may help to understand the involvement of TH in lamprey metamorphosis. Indeed, there is a shift in monodeiodinase pathways between larval and adult life in lampreys that may account for the decline in serum levels of $\mathrm{TH}$ at the beginning of the metamorphosis [30]. In addition, a reduction in the capacity of T3 nuclear receptors in hepatocytes following larval life may reflect the importance of this hormone to the larval phases of growth and metamorphosis [78].

All these data, even if still controversial, suggest that, lamprey metamorphosis is unlike any other vertebrate metamorphosis in that $\mathrm{TH}$ appear to be antagonistic (inhibitory) to the process. Indeed, in contrast to amphibians, in lampreys, induction of metamorphosis seems to be driven by a drop of TH [158].

These two opposite examples show that, during the evolution of vertebrates, the role of thyroid hormones in the endocrinology of larval metamorphosis may have differed dramatically, being possibly inhibitory in lampreys and stimulatory in amphibians.

\section{Neuroendocrine control of larval metamorphosis in teleosts}

Typical larval metamorphosis in teleost fish is restricted to Anguilliformes, Elopiformes, Notacanthiformes and Pleuronectiformes [158]. The two groups, Anguilliformes and Pleuronectiformes, represent one of the most ancient and one of the most recent groups of teleosts, respectively. This suggests that larval metamorphosis may have been acquired independently by these two groups during teleost evolution. The alternative hypothesis would be that larval metamorphosis could have been lost in most other teleost groups. The most spectacular (and studied) larval metamorphoses in teleosts are the metamorphosis from leptocephalus larva to glass eels and the flatfish metamorphosis.

\section{(1) Anguilliformes}

Early studies on leptocephali of Anguilla anguilla showed increased thyroid gland development [96] and activation [128] during metamorphosis, a result later confirmed in Conger myriaster [71, 153]. During early metamorphosis, T4 body content increases about sixfold in C. myriaster, and then decreases as metamorphosis progresses; $\mathrm{T} 3$ body content increases gradually in 
early metamorphosis and then increases abruptly (about 13 -fold) toward the end of the period [153]. In agreement, histological evidence revealed an activation of the thyroid gland [153].

Exogenous thyroid hormone has been shown to stimulate metamorphosic changes in leptocephali of Conger myriaster [69] and of Anguilla anguilla [149], confirming the major role of $\mathrm{TH}$ in the induction of elopomorph larval metamorphosis.

\section{(2) Pleuronectiformes (flatfish)}

Hormone assays in flatfish showed a surge in $\mathrm{TH}$ concentration during metamorphosis with a peak around the time of metamorphic climax [17, 50]; Japanese flounder, Paralichthys olivaceus: [90, 139]). In agreement with the activation of the thyroid function during larval metamorphosis, histological study of the pituitary also showed an activation of TSH cells (plaice, Pleuronectes platessa: [128]; Japanese flounder: [87]).

Accordingly, early works by Miwa and Inui [61, 88 ] in flounder (Paralichthys olivaceus) reported that exogenous TH could induce metamorphosis (eye migration, settling behavior and length of second dorsal fin ray) with the production of a miniature of the normally metamorphosed juvenile, while thiourea treatment arrested the metamorphic process of the fish. Subsequent experimental studies by various authors have demonstrated that $\mathrm{TH}$ treatment was able to induce the many morphological, physiological and behavioral changes, characteristics of flatfish metamorphosis, such as shift in erythrocyte populations [89], histological and biochemical changes in muscle [153], development of gastric glands [57, 91, 131], changes of gill mitochondria-rich cells from larval to juvenile form [121] and bone remodelling for eye relocation [100, 132]. Also, [62] showed that injection of bovine TSH into flounder larvae increased tissue concentrations of T4 and accelerated the metamorphic process, such as shortening of the second fin ray and eye migration.

These data demonstrated that the thyrotropic axis (TSH-T4/T3) would be the main axis controlling metamorphosis in flatfish. However, nothing is yet known on the brain neurohormones potentially involved in this activation.

Beside the thyrotropic axis, cortisol was shown to synergize with thyroid hormones, while sex steroids and prolactin exhibited an antagonist effect (for review: [20]; Japanese flounder: [18, 19]), in agreement with data in amphibians. Changes in tissue cortisol concentrations closely parallel those of thyroid hormones, except that cortisol peaks a few days earlier than T4 (Japanese flounder: [17]). Both PRL and growth hormone $(\mathrm{GH})$ expression increased gradually but steadily during metamorphosis and showed a dramatic rise in post-climax fish [20]. In contrast, tissue levels of estradiol and testosterone remain low and do not show marked change during metamorphosis [16].

These data demonstrated the involvement of thyroid hormones as major triggers of metamorphosis in eels as in flatfish. Further studies are clearly needed to investigate the potential synergistic or antagonistic roles of other hormones as well as to determine the brainpituitary control of thyroid function.

A few data in adult teleosts suggest also a role for $\mathrm{CRH}$ and/or TRH in the control of TSH, with variations possibly depending on species or physiological status (coho salmon: [73]; European eel: [109]). Further studies are clearly needed to investigate which brain neuromediator is specifically implicated in the triggering of larval metamorphosis in teleosts.

In conclusion, these data indicate that thyroid hormones play a key role in the induction of larval metamorphoses in teleosts, as well as in amphibians, while in lampreys TH would be inhibitory. This suggests that the stimulatory role of TH in metamorphosis may have been acquired in a common ancestor of teleosts (actinopterygian lineage) and amphibians (sarcopterygian lineage) posteriorly to the emergence of agnathans. An alternative hypothesis is that the stimulatory role of TH in larval metamorphosis could have been acquired independently in amphibians and in teleosts.

\section{NEUROENDOCRINE CONTROL OF SECONDARY METAMORPHOSES}

Secondary metamorphoses have been described in some diadromous migratory teleosts. They prepare the fish to the river downstream migration, to the transfer from fresh to seawater and finally to the oceanic migration.

\section{Neuroendocrine control of smoltification}

In teleosts, a well-known example of "secondary metamorphosis" is provided by smoltification in salmons. This transformation from parr to smolt, which occurs in the river, encompasses various morphological (silvering of the body color), physiological (osmoregulation, vision) and behavioral (rheotaxism) changes, and preadapts the smolt to its future oceanic growth ecophase [5]. According to the crucial role of smoltification in the salmon capacity to adapt to seawater and thus in the success of its biological cycle and aquaculture, many investigations have been performed on the endocrine control of smoltification.

A number of endocrine investigations emphasized 
the role of TH in these changes. Thyroid involvement in smoltification was originally suggested by Hoar [51] who observed histological activation of thyroid tissue of the Atlantic salmon (Salmo salar). The availability of radioimmunassay (RIA) procedures has enabled different groups to demonstrate T4 and T3 surges during the smoltification process $[52,53]$. Moreover, the administration of exogenous TH to juvenile parr-status salmonids results in morphological and physiological changes, which are consistent with the parr-smolt transformation [27, 34, 49, 84, 113, 135].

Many other studies revealed the key-role in smoltification of other hormones, such as growth hormone $(\mathrm{GH})$ and cortisol. Hypertrophy and hyperplasia of somatotrophs [27] and a rise in plasma $\mathrm{GH}$ have been observed during smoltification (coho salmon: [137, 138, 155]; Atlantic salmon: [110]). Moreover, administration of GH clearly improves hypo-osmoregulatory ability and seawater survival of parr (for review: [5, 27]). In addition, $\mathrm{GH}$ treatment also induces other smoltificationrelated changes, such as condition factor and skin pigmentation [27]. Variations of plasma levels of cortisol suggest a potential synergistic role during smoltification $[133,150]$. Data suggest that cortisol could also play a significant stimulatory role in osmoregulation. Indeed, prolonged cortisol treatment in pre-smolt coho salmon caused an increase in $\mathrm{Na}+/ \mathrm{K}+-\mathrm{ATPase}$ activity, while treatment of smolts had no effect [112].

This is leading to a complex scheme of the pituitary control of smoltification. Moreover, neuroendocrine investigations on the brain components of the control of smoltification are still lacking.

\section{Neuroendocrine control of silvering}

Another exemple of "secondary metamorphosis" is provided by another migratory teleost, the eel. Silvering, which transforms the yellow eel into the silver eel, shares many similarities with smoltification, such as change in body color, preparation to osmoregulation in seawater, and downstream migratory behavior. Because of these analogies, it had been classically assumed that silvering and smoltification would be under a similar endocrine control. However, our recent studies have contributed to reveal striking discrepancies, with a potential key-role of the gonadotropic axis in the induction of silvering. Indeed, a significant increase in FSH( mRNA level could be observed during the early stages of silvering and may correspond to the first appearance of lipid vesicles in oocytes (endogenous vitellogenesis) [3]. This increase in $\mathrm{FSH} \beta$ is followed by a sharp increase in $\mathrm{LH} \beta$ mRNA levels at the late stages, which may be related to the beginning of exogenous vitellogenesis [3]. At the peripheral level, sig- nificant increases in plasma levels of sex steroids (oestradiol, testosterone and the teleost specific andogen, 11-ketotestosterone) have been measured between yellow and silver stages (A. australis and A. dieffenbachii: [3, 120]; A. anguilla: [79]; A. rostrata: [14]; A. japonica: [47]). This control strongly differs from smoltification, which is in contrast inhibited by sex steroids.

Experimental data using exogenous sex steroids are in agreement with the involvement of the gonadotropic axis in the induction of silvering, as treatment with androgens can induce increases of eye diameter [3, 114] and of skin thickness [114], regression of digestive tract $[3,114]$ in yellow eels, and amplification of silvering parameters in silver eels (eye diameter: [6, 102]; skin thickness and darkening: [102]; regression of the digestive tract: [148]).

In contrast, measurement of pituitary TSH mRNAs and plasma levels of TH during silvering shows no change in TSH and T3, and a moderate increase in T4 (Anguilla anguilla: [3]; Anguilla japonica: [48]). Similarly, no increases were observed in GH plasma levels, pituitary content neither in GH mRNA levels throughout silvering in European eel [3].

This discrepancy is likely related to the position of silvering versus smoltification in the migratory fish life cycle, silvering corresponding to the initiation of the reproductive phase in the ocean, while smoltification prepares the fish to the growth phase. The similarities of the morpho-physiological and behavioral changes between the two species indicate remarkable evolutionary convergences in the morphogenetic roles and target tissues of $\mathrm{TH}$ and sex steroids for the induction of secondary metamorphoses. Furthermore our ongoing studies suggest a synergistic role of glucocorticosteroids on sex steroid-induction of silvering parameters [56, 119], a synergism recalling that observed with TH during larval and possibly also secondary metamorphosis.

It is of great interest to note that while smoltification and silvering share many similarities in term of morphological changes, the endocrinology of these two secondary metamorphoses drastically differs, with the major involvement of different neuroendocrine axes, the thyrotropic/somatotropic one for smoltification and the gonadotropic one for silvering. This suggests that secondary metamorphoses may have been acquired independently, via different endocrine mechanisms, during teleost evolution. The convergence between some morphological (skin silvering, eye size and pigments), metabolic and behavioural changes reflects that the control of the same peripheral target organs (skin, eye, muscle...) and target genes is exerted by different hormonal receptors (thyroid hormone receptors in salmon versus androgen receptors in the eel). 


\section{CONCLUSIONS: COMPARATIVE NEUROENDOCRINOLOGY OF PUBERTY AND METAMORPHOSIS.}

\section{Neuroendocrine "crises"}

Metamorphosis and puberty are triggered by transient activations of neuroendocrine axes namely of the thyrotropic axis for classical larval metamorphosis and the gonadotropic axis for puberty. Beside this classical scheme, more complex situations are revealed. As discussed above, other axes, such as the somatotropic and corticotropic axes, may also play a key-synergistic role in the induction of all morphological, physiological and behavioral changes characteristic of metamorphosis and puberty. Furthermore, distinction between metamorphosis and puberty vanishes when studying a traditionally so-called "secondary metamorphosis" such as silvering in the eel.

Common features are the transient and large activation of brain-pituitary-peripheral neuroendocrine axes ("neuroendocrine crises") during which classical regulations such as homeostatic maintenance of hormones levels and negative feedbacks may be overruled. Thus, in teleosts, strong positive feedbacks by sex steroids on the brain and pituitary have been evidenced that are largely amplifying the activation of the gonadotropic axis at puberty. In other cases, a reset of negative feedbacks to another threshold level may occur.

The "neuroendocrine crises" also reflect the keyrole of the brain in the timing and coordination of these developmental events. Internal and environmental cues (triggering signals) are integrated at the brain level leading to the activation of specific neuroendocrine axes. Coordinated implication of neuroendocrine axes may result from common brain control. Such a case is exemplified by the common role of $\mathrm{CRH}$ in the corticotropic axis and thyrotropic axis at metamorphosis in amphibians and also possibly in fish. Interrelationships between neuroendocrine axes may also result from interaction by peripheral hormones. For instance we could demonstrate stimulatory roles of cortisol (corticotropic axis) and IGF (somatotropic axis) in the pubertal simulation of LH (gonadotropic axis) in the eel $[58,59,117]$.

\section{Triggering signals}

Comparison between puberty and metamorphosis may also favor our understanding of the triggering signals of these postembryonic developmental events. For instance, metamorphoses as well as puberty or even sex change, should occur only when body size and energy stores are sufficient enough to allow the success of the next phase (migration/reproduction) [125]. Thus, metabolic signals such as insulin-growth factors or the more recently discovered hormone, leptin and ghrelin, could likely be involved in the triggering of both types of events (mammals: [15, 33, 41, 147]; non-mammals: $[101,125])$. Comparative studies would help deciphering the brain networks implied in the integration of the internal and environmental signals of puberty/ metamorphosis, as well as the pathways of the activation of the gonadotropic /thyrotropic and corticotropic axes, respectively. In teleosts, the large plasticity in the occurrence and timing of metamorphosis and puberty, which contributes to the high diversity of fish life cycles, may provide new and relevant models to such investigations.

\section{Threats on metamorphosis and puberty: Environmen- tal and endocrine disruptions}

The crucial morphogenetic roles of TH and steroids at the time of metamorphosis and puberty, as well as their role on peripheral and central (feedback actions on the brain and pituitary) target tissues, make the organism particularly vulnerable to the endocrine disrupting effects of xenobiotics. Furthermore, aquatic species are specially concerned by the increasing number of endocrine disruptors, currently accumulating in fresh as well as in marine hydrosystems. Indeed, the aquatic existence means that the animal is bathed constantly in a solution containing pollutants, and that uptake of chemicals readily occurs via the gills and skin, in addition to the diet. Impacts of contaminants are various and range from subtle changes in the physiology and sexual behavior to permanently altered sexual differentiation and impairment of fertility (wild freshwater fish: [63]; marine fish: [83]; invertebrates: [99]; aquatic mammals: [37]; amphibians: [42]; reptiles: [46]). In fish, the three major neuroendocrine axes involved in the control of puberty and metamorphoses: HPG (hypothalamo-pituitary-gonads), HPT (hypothalamopituitary-thyroids) and HPI (hypothalamo-pituitaryinterrenals) are potentially affected by endocrine disruptors (for reviews: freshwater fish: [63]; marine fish: [83]).

\section{REFERENCES}

1. Aizen, J., Meiri, I., Tzchori, I., Levavi-Sivan, B., and Rosenfeld, H., "Enhancing Spawning in the Grey Mullet (Mugil cephalus) by Removal of Dopaminergic Inhibition," General and Comparative Endocrinology, Vol. 142, pp. 212-221 (2005).

2. Allen, B.M., "Extirpation Experiments in Rana Pipiens Larva," Science, Vol. 44, pp. $755-757$ (1916). 
3. Aroua, S., Schmitz, M., Baloche, S., Vidal, B., Rousseau, K., and Dufour, S., "Endocrine Evidence That Silvering, a Secondary Metamorphosis in the Eel, Is a Pubertal Rather Than a Metamorphic Event," Neuroendocrinology, Vol. 82, pp. 221-232 (2005).

4. Baroiller, J.F., Guiguen, Y., and Fostier, A., "Endocrine and Environmental Aspects of Sex Differentiation in Fish," Cellular and Molecular Life Sciences, Vol. 55, pp. 910-931 (1999).

5. Boeuf, G., "Salmonid Smolting: a Pre-adaptation to the Oceanic Environment," In Rankin, J.C. and Jensen, F. B. (eds), Fish Ecophysiology, Chapman and Hall, London, pp. 105-135 (1993).

6. Boëtius, I. and Larsen, L.O., "Effects of Testosterone on Eye Size and Spermiation in Silver Eels, Anguilla anguilla," General and Comparative Endocrinology, Vol. 82, pp. 238 (1991).

7. Bronson, F.H., "Puberty and Energy Reserves: a Walk on the Wild Side," In Walken, K. and Schneider, J.E. (eds), Reproduction in Context, MIT Press, Cambridge, MA, pp. 15-33 (2000).

8. Carrasco, N., "Iodide Transport in the Thyroid Gland," Biochimica et Biophysica Acta, Vol. 1154, pp. 65-82 (1992).

9. Chang, J.P. and Peter, R.E., "Effects of Dopamine on Gonadotropin Release in Female Goldfish, Carassius auratus," Neuroendocrinology, Vol. 36, pp. 351-357 (1983).

10. Chang, J.P., Peter, R.E., Nahorniak, C.S., and Sokolowska, M., "Effects of Catecholaminergic Agonists and Antagonists on Serum Gonadotropin Concentrations and Ovulation in Goldfish: Evidence for Specificity of Dopamine Inhibition of Gonadotropin Secretion," General and Comparative Endocrinology, Vol. 55, pp. 351-360 (1984).

11. Chang, J.P., Yu, K.L., Wong, A.O., and Peter, R.E., "Differential Actions of Dopamine Receptor Subtypes on Gonadotropin and Growth Hormone Release in vitro in Goldfish," Neuroendocrinology, Vol. 51, pp. 664-674 (1990).

12. Colledge, W.H., "GPR54 and Puberty," Trends Endocrinol and Metab, Vol. 15, pp. 448-453 (2004).

13. Copeland, P.A. and Thomas, P., "Control of Gonadotropin Release in the Atlantic Croaker (Micropogonias undulatus): Evidence for Lack of Dopaminergic Inhibition," General and Comparative Endocrinology, Vol. 74, pp. 474-483 (1989).

14. Cottrill, R.A., McKinley, R.S., Van der Kraak, G., Dutil, J.-D., Reid, K.B., and McGrath, K.J., "Plasma Non-esterified Fatty Acid Profiles and 17b-Oestradiol Levels of Juvenile Immature and Maturing Adult American Eels in the St Lawrence River," Journal of Fish Biology, Vol. 59, pp. 364-379 (2001).

15. Daftary, S.S. and Gore, A.C., "IGF-1 in the Brain as a
Regulator of Reproductive Neuroendocrine Function," Experimental Biology and Medicine, Vol. 230, pp. 292306 (2005).

16. de Leeuw, R., Goos, H.J., and Van Oordt, P.G., "The Dopaminergic Inhibition of the Gonadotropin-Releasing Hormone-Induced Gonadotropine Release: an in vitro Study with Fragments and Cell Suspensions from Pituitaries of the African Catfish, Clarias gariepinus (Burchell)," General and Comparative Endocrinology, Vol. 63, pp. 171-177 (1986).

17. de Jesus, E.G., Hirano, T., and Inui, Y., "Changes in Cortisol and Thyroid Hormone Concentrations during Early Development and Metamorphosis in the Japanese Flounder, Paralichthys olivaceus," General and Comparative Endocrinology, Vol. 82, pp. 369-376 (1991).

18. de Jesus, E.G., Hirano, T., and Inui, Y., "Gonadal Steroids Delay Spontaneous Flounder Metamorphosis and Inhibit T3-Induced Fin Ray Shortening in vitro," Zoological Science, Vol. 9, pp. 633-638 (1992).

19. de Jesus, E.G., Hirano, T., and Inui, Y., "Flounder Metamorphosis: Its Regulation by Various Hormones," Fish Physiology and Biochemistry, Vol. 11, pp. 323328 (1993).

20. de Jesus, E.G., Hirano, T., and Inui, Y., "The Antimetamorphic Effect of Prolactin in the Japanese Flounder," General and Comparative Endocrinology, Vol. 93, pp. 44-50 (1993).

21. de Roux, N., Genin, E., Carel, J.C., Matsuda, F., Chaussain, J.L., and Milgrom, E., "Hypogonadotropic Hypogonadism due to Loss of Function of the KiSS1Derived Peptide Receptor GPR54," Proceedings of the National Academy of Science U.S.A., Vol. 100, pp. 10972-6 (2003).

22. Denver, R.J., "Acceleration of Anuran Amphibian Metamorphosis by Corticotropin Releasing Hormonelike Peptides," General and Comparative Endocrinology, Vol. 91, pp. 38-51 (1993).

23. Denver, R.J., "Evolution of the Corticotropin-Releasing Hormone Signaling System and its Role in Stressinduced Phenotypic Plasticity," Annals of the New York Academy of Sciences, Vol. 897, pp. 46-53 (1999).

24. Denver, R.J. and Licht, P., "Neuropeptide Stimulation of Thyrotropin Secretion in the Larval Bullfrog: Evidence for a Common Regulator of Thyroid and Interregnal Activity during Metamorphosis," Journal of Experimental Zoology, Vol. 252, pp. 101-104 (1989).

25. Dhillo, W.S., Chaudhri, O.B., Patterson, M., Thompson, E.L., Murphy, K.G., Badman, M.K., McGowan, B.M., Amber, V., Patel, S., Ghatei, M.A., and Bloom, S.R., "Kisspeptin-54 Stimulates the Hypothalamic-Pituitary Gonadal Axis in Human Males," Journal of Clinical Endocrinology and Metabolism, Vol. 90, pp. 66096615 (2005).

26. Dodd, M.H.I. and Dodd, J.M., "The Biology of 
Metamorphosis," In Lofts, E. (eds), Physiology of Amphibia, Academic Press, New York, Vol. 3, pp 467599 (1976).

27. Donaldson, E., Fagerlund, U., Higgs, D., and McBride, J., "Hormonal Enhancement of Growth," In Hoar, W. S., Randall, D.J. and Brett, J.R. (eds), Fish Physiology, Academic Press, New York, Vol. VIII,.pp. 456-597 (1979).

28. Dufour, S., Lopez, E., Le Menn, F., Le Belle, N., Baloche, S., and Fontaine, Y.A., "Stimulation of Gonadotropin Release and of Ovarian Development, by the Administration of a Gonadoliberin Agonist and of Dopamine Antagonists, in Female Silver Eel Pretreated with Estradiol," General and Comparative Endocrinology, Vol. 70, pp. 20-30 (1988).

29. Dufour, S., Weltzien, F.A., Sébert, M.E., Le Belle, N., Vidal, B., Vernier, P., and Pasqualini, C., "Dopaminergic Inhibition of Reproduction in Teleost Fishes: Ecophysiological and Evolutionary Implications," Annals of the New York Academy of Sciences, Vol. 1040, pp. 921 (2005).

30. Eales, J.G., Holmes, J.A., McLeese, J.M., and Youson, J.H., "Thyroid Hormone Deiodination in Various Tissues of Larval and Upstream-Migrant Sea Lampreys, Petromyzon marinus," General and Comparative Endocrinology, Vol. 106,pp. 202-210 (1997).

31. Ebling, F.J.P., "The Neuroendocrine Timing of Puberty," Reproduction, Vol. 129, pp. 675-683 (2005).

32. Eddy, L. and Lipner, H., "Amphibian Metamorphosis: Role of Thyrotropin-Like Hormone," General and Comparative Endocrinology, Vol. 29, pp. 333-336 (1976).

33. Fernandez-Fernandez, R., Martini, A.C., Navarro, V. M., Castellano, J.M., Dieguez, C., Aguilar, E., Pinilla, L., and Tena-Sempere, M., "Novel Signals for the Integration of Energy Balance and Reproduction," Molecular and Cellular Endocrinology, Vol. 254-255, pp. 127-132 (2006).

34. Fontaine, M., "Physiological Mechanisms in the Migration of Marine and Amphihaline Fish," Advances in Marine Biology, Vol. 13, pp. 241-255 (1975).

35. Forey, P. and Janvier, P., "Agnathans and the Origin of Jawed Vertebrates," Nature, Vol. 361, pp. 129-134 (1993).

36. Forey, P. and Janvier, P., "Evolution of the Early Vertebrates," American Scientist, Vol. 82, pp. 554-565 (1994).

37. Fossi, M.C. and Marsili, L., "Effects of Endocrine Disrupors in Aquatic Mammals," Pure and Applied Chemistry, Vol. 75, pp. 2235-2247 (2003).

38. Frisch, R. and McArthur, J., "Menstrual Cycles: Fatness as a Determinant of Minimum Weight for Height Necessary for Their Maintenance or Onset," Science, Vol. 185, pp. 949-951 (1974).

39. Frisch, R. and Revelle, R., "Height and Weight at
Menarche: a Hypothesis of Critical Body Weights and Adolescent Events," Science, Vol. 169, pp. 397-399 (1970).

40. Funes, S., Hedrick, J.A., Vassileva, G., Markowitz, L., Abbondanzo, S., Golovko, A., Yang, S., Monsma, F.J., and Gustafson, E.L., "The KiSS-1 Receptor GPR54 is Essential for the Development of the Murine Reproductive System," Biochemical and Biophysical Research Communications, Vol. 312, pp. 1357-63 (2003).

41. Garcia, M.C., Lopez, M., Alavarez, C.V., Casanueva, F., Tena-Sempere, M. and Dieguez, C., "Role of Ghrelin in Reproduction," Reproduction, Vol. 133, pp. 531-540 (2007).

42. Gardiner, D., Ndayibagira, A., Grun, F., and Blumberg, B., "Deformed Frogs and Environmental Retinoids," Pure and Applied Chemistry, Vol. 75, pp. 2263-2273 (2003).

43. Gerlach, T. and Aurich, J.E., "Regulation of Seasonal Reproductive Activity in the Stallion, Ram and Hamster," Animal Reproduction Science, Vol. 58, pp. 197213 (2000).

44. Gottsch, M.L., Cunningham, M.J., Smith, J.T., Popa, Sm., Acohido, B.V., Crowley, W.F., Seminara, S., Clifton, D.K., and Steiner, R.A., "A Role for Kisspeptins in the Regulation of Gonadotropin Secretion in the Mouse," Endocrinology, Vol. 145, pp. 4073-4077 (2004).

45. Gudernatsch, J.F., "Feeding Experiments on Tadpoles. I. The Influence of Specific Organs Given as Food on Growth and Differentiation. A Contribution to the Knowledge of Organs with Internal Secretion," Archiv für Entwicklungsmechanik der Organismen, Vol. 35, pp. 457-483 (1912).

46. Guillette, L.J. and Iguchi, T., "Contaminant-Induced Endocrine and Reproductive Alterations in Reptiles," Pure and Applied Chemistry, Vol. 75, pp. 2275-2286 (2003).

47. Han, Y.-S., Liao, I.-C., Tzeng, W.-N., Huang, Y.-S., and Yu, J. Y.-L., "Serum Estradiol-17 $\beta$ and Testosterone Levels during Silvering in Wild Japanese Eel Anguilla Japonica," Comparative Biochemistry and Physiology, Vol. 136B, pp. 913-920 (2003).

48. Han, Y.-S., Liao, I.-C., Tzeng, W.-N., and Yu, J. Y.-L., "Cloning of the cDNA for Thyroid Stimulating Hormone $\beta$ Subunit and Changes in Activity of the Pituitary-thyroid Axis during Silvering of the Japanese Eel," Journal of Molecular Endocrinology, Vol. 32, pp. 179-194 (2004).

49. Higgs, D.A., Fagerland, U.H.M., Eales, J.G., McBride, R.E., "Application of Thyroid and Steroid Hormones as Anabolic Agents in Fish Culture," Comparative Biochemistry and Physiology, Vol. 73B, pp. 143-176(1982).

50. Hiroi, J., Sakakura, Y., Tagawa, M., Seikai, T., and Tanaka, M., "Developmental Changes in Low-Salinity 
Tolerance and Responses of Prolactin, Cortisol, and Thyroid Hormones to Low-Salinity Environment in Larvae and Juveniles of Japanese Flounder, Paralichthys olivaceus," Zoological Science, Vol. 14, pp. 987-992 (1997).

51. Hoar, W.S., "The Thyroid Gland of the Atlantic Salmon," Journal of Morphology, Vol. 65, pp. 257-295 (1939).

52. Hoar, W.S., "Smolt Transformation: Evolution, Behaviour and Physiology," Journal of the Fisheries Research Board of Canada, pp. 1233-1252 (1976).

53. Hoar, W.S., "The Physiology of Smolting Salmonids," In Hoar, W.S. and Randall, D.J. (eds), Fish Physiology, Academic Press, New York, Vol. 11B, pp. 275-343 (1988).

54. Hoheisel, G. and Sterba, G., "Uber die Wirkung von Kaliumperchlorat $(\mathrm{KClO} 4)$ auf Ammocoeten von Lampetra planeri Bloch," Zeitschrift Fur MikroskopischAnatomische Forschung, Vol. 70, pp. 490-516 (1963).

55. Holland, M.C., Hassin, S., and Zohar, Y., "Effects of Long-Term Testosterone, Gonadotropin-Releasing Hormone Agonist, and Pimozide Treatments on Gonadotropin II levels and Ovarian Development in Juvenile Female Striped bass (Morone saxatilis)," Biology Reproduction, Vol. 59, pp. 1153-1162 (1998).

56. Huang, Y.S., "Rôle des Stéroides Sexuels et des Hormones Métaboliques dans le Contrôle Direct Hypophysaire de l'hormone Gonadotrope (GtH-II) chez l'anguille Européenne, Anguilla anguilla," $\mathrm{PhD}$ thesis, University Paris VI (1998).

57. Huang, L., Schreiber, A.M., Soffientino, B., Bengtson, D.A., and Specker, J.L., "Metamorphosis of Summer Flounder (Paralichthys dentatus): Thyroid Status and the Timing of Gastric Gland Formation," Journal of Experimental Zoology, Vol. 280, pp. 413-420 (1998).

58. Huang, Y.S., Rousseau, K., Le Belle, N., Vidal, B., Burzawa-Gérard, E., Marchelidon, J., and Dufour, S., "Insulin-Like Growth Factor-I Stimulates Gonadotropin Production from Eel Pituitary Cells: a Possible Metabolic Signal for Induction of Puberty," Journal of Endocrinology, Vol. 159, pp. 43-52 (1998).

59. Huang, Y.S., Rousseau, K., Sbaihi, M., Le Belle, N., Schmitz, M., Dufour, S., "Cortisol Selectively Stimulates Pituitary Gonadotropin $\beta$-Subunit in a Primitive Teleost, Anguilla anguilla," Endocrinology, Vol. 140, pp. 1228-1235 (1999).

60. I'Anson, H., Foster, D.L., Foxcroft, G.R., and Booth, P. J., "Nutrition and Reproduction," Oxford. Reviews of Reproductive Biology, Vol. 13, pp. 239-311 (1991).

61. Inui, Y. and Miwa. S., "Thyroid Hormone Induces Metamorphosis of Flounder Larvae," General and Comparative Endocrinology, Vol. 60, pp. 450-454 (1985).

62. Inui, Y., Tagawa, M., Miwa, S., and Hirano, T., "Effects of Bovine TSH on the Tissue Thyroxine Level and
Metamorphosis in Prometamorphic Flounder Larvae," General and Comparative Endocrinology, Vol. 74, pp. 406-410 (1989).

63. Jobling, S. and Tyler, C.R., "Endocrine Disruption in Wild Freshwater Fish," Pure Applied Chemistry, Vol. 75, pp. 2219-2234 (2003).

64. Kah, O., Chambolle, P., Thibault, J., and Geffard, M., "Existence of Dopaminergic Neurons in the Preopric Region of the Goldfish," Neuroscience Letters, Vol. 48, pp.293-298 (1984).

65. Kah, O., Dubourg, P., Onteniente, B., Geffard, M., and Calas, A., "The Dopaminergic Innervation of the Goldfish Pituitary. An Immunocytochemical Study at the Electron-Microscope Level using Antibodies Against Dopamine," Cell and Tissue Research, Vol. 244, pp. 577-582 (1986).

66. Kah, O., Dulka, J.G., Dubourg, P., Thibault, J., and Peter, R.E., "Neuroanatomical Substrate for the Inhibition of Gonadotrophin Secretion in Goldfish: Existence of a Dopaminergic Preoptico-Hypophyseal Pathway," Neuroendocrinology, Vol. 45, pp. 451-458 (1987).

67. Kanamori, A. and Brown, D.D., "The Analysis of Complex Developmental Programmes: Amphibian Metamorphosis," Genes to Cells, Vol. 1, pp. 429-435 (1996).

68. Kennedy, G.C. and Mitra, J., "Body Weight and Food Intake as Initiating Factors for Puberty in the Rat," Journal of Physiology, Vol. 166, pp. 408-418 (1963).

69. Kitajima, C., Sato, T., and Kawanishi, M., "On the Effect of Thyroxine to Promote the Metamorphosis of a Conger Eel-Preliminary Report," Bulletin of the Japanese Society of Scientific Fisheries, Vol. 33, pp. 919922 (1967).

70. Kikuyama, S., Kawamura, K., Tanaka, S., and Yamamoto, K., "Aspects of Amphibian Metamorphosis, Hormonal Control," International Review of Cytology, Vol. 145, pp. 105-148 (1993).

71. Kubota, S.S., "Studies on the Ecology, Growth and Metamorphosis in Conger Eel, Conger myriaster (Brevoort)," Journal of Faculty of Fish Prefectural University of Mie, Vol. 5, pp. 190-370 (1961).

72. Kumakura, N., Okuzawa, K., Gen, K., and Kagawa, H., "Effects of Gonadotropin-Releasing Hormone Agonist and Dopamine Antagonist on Hypothalamus-Pituitarygonadal Axis of Prepubertal Female Eed Seabream (Pagrus major)," General and Comparative Endocrinology, Vol. 131, pp. 264-273 (2003).

73. Larsen, D.A., Swanson, P., Dickey, J.T., Rivier, J., and Dickhoff, W.W., "In Vitro Thyrotropin-Releasing Activity of Corticotropin-Releasing Hormone-Family Peptides in Coho Salmon, Oncorhynchus kisutch," General and Comparative Endocrinology, Vol. 109, pp. 276-285 (1998).

74. Leatherland, J.F., Hilliard, R.W., Macey, D.J., and 
Potter, I.C., "Changes in Serum Thyroxine and Triiodothyronine Concentrations during Metamorphosis of the Southern Hemisphere Lamprey Geotria australis, and the Effect of Propylthiouracil, Triiodothyronine and Environmental Temperature on Serum Thyroid Hormone Concentrations of Ammocoetes," Fish Physiology and Biochemistry, Vol. 8, pp. 167-177 (1990).

75. Lin, H.R., Van der Kraak, G., Zhou, X.J., Liang, J.Y., Peter, R.E., Rivier, J.E., and Vale, W.W., "Effects of [D-Arg6, Trp7, Leu8, Pro9NEt]-Luteinizing HormoneReleasing Hormone (sGnRH-a) and [D-Ala6, Pro9NEt]Luteinizing Hormone-Releasing Hormone (LHRH-a), in Combination with Pimozide or Domperidone, on Gonadotropin Release and Ovulation in the Chinese Loach and Common Carp," General and Comparative Endocrinology, Vol. 69, pp. 31-40 (1998).

76. Linard, B., Bennami, S., and Saligaut, C., "Involvement of Estradiol in a Catecholamine Inhibitory Tone of Gonadotropin Release in Rainbow Trout (Oncorhynchus mykiss)," General and Comparative Endocrinology, Vol. 99, pp. 192-196 (1995).

77. Lintlop, S.P. and Youson, J.H., "Concentration of Triidothyronine in the Sera of the Sea Lamprey, Petromyzon Marinus, and the Brook Lamprey, Lampetra Lamottenii at Various Phases of Their Life Cycle," General and Comparative Endocrinology, Vol. 49, pp. 187-194 (1983).

78. Lintlop, S.P. and Youson, J.H., "Binding of Triiodothyronine to Hepatocyte Nuclei from Sea Lamprey, Petromyzon marinus L., at Various Stages of the Life Cycle," General and Comparative Endocrinology, Vol. 49, pp. 428-436 (1983).

79. Lokman, P.M., Vermeulen, G.J., Lambert, J.G.D., and Young, G., "Gonad Histology and Plasma Steroid Profiles in Wild New Zealand Freshwater Eels (Anguilla dieffenbachii and A. australis) before and at the Onset of the Natural Spawning Migration. I. Females," Fish Physiology and Biochemistry, Vol. 19, pp. 325-338 (1998).

80. Manzon, R.G. and Denver, R.J., "Regulation of Pituitary Thyrotropin Gene Expression during Xenopus Metamorphosis: Negative Feedback is Functional Throughout Metamorphosis," Journal of Endocrinology, Vol. 182, pp. 273-285 (2004).

81. Manzon, R.G. and Youson, J.H., "The Effects of Exogenous Thyroxine (T4) or Triiodothyronine (T3) in the Presence or Absence of Potassium Perchlorate, on the Incidence of Metamorphosis and on Serum T4 and T3 Concentrations in Larval Sea Lampreys (Petromyzon marinus L.)." General and Comparative Endocrinology, Vol. 106, pp. 211-220 (1997).

82. Matsui, H., Takatsu, Y., Kumano, S., Matsumoto, H., and Ohtaki, T., "Peripheral Administration of Metastin Induces Marked Gonadotropin Release and Ovulation in the Rat," Biochemical and Biophysical Research Communications, Vol. 320, pp. 383-388 (2004).

83. Matthiessen, P., "Endocrine Disruption in Marine Fish," Pure Applied Chemistry, Vol. 75, pp. 2249-2261 (2003).

84. McBride, J.R., Higgs, D.A., Fagerlund, U.H.M., Buckley, J.T., "Thyroid Hormones and Steroid Hormones: Potential for Control of Growth and Smoltification of Salmonids," Aquaculture, Vol. 28, pp. 201-210 (1982).

85. McNabb, F.M.A., Thyroid Hormones, Englewood Cliffs, Prentice Hall, pp. 283 (1992).

86. Messager, S., Chatzidaki, E.E., Ma, D., Hendrick, A.G., Zahn, D., Dixon, J., Thresher, R.R., Malinge, I., Lomet, D., Carlton, M.B., Colledge, W.H., Caraty, A., and Aparicio, S.A., "Kisspeptin Directly Stimulates Gonadotropin-Releasing Hormone Release Via G ProteinCoupled Receptor 54," Proceedings of the National Academy of Science U.S.A., Vol. 102, pp. 1761-6 (2005).

87. Miwa, S. and Inui, Y., "Histological Changes in the Pituitary-Thryoid Axis during Spontaneous and Artificially-Induced Metamorphosis of Larvae of the Flounder Paralichtys olivaceus," Cell and Tissue Research, Vol. 249, pp.117-123 (1987).

88. Miwa, S. and Inui, Y., "Effects of Various doses of Thyroxine and Triidothyronine on the Metamorphosis of Flounder (Paralichtys olivaceus)," General and Comparative Endocrinology, Vol. 67, pp. 356-363 (1987).

89. Miwa, S. and Inui, Y., "Thyroid Hormone Stimulates the Shift of Erythrocyte Populations during Metamorphosis of the Flounder," Journal of Experimental Zoology, Vol. 259, pp. 222-228 (1991).

90. Miwa, S., Tagawa, M., Inui, Y., and Hirano, T., "Thyroxine Surge in Metamorphosing Flounder Larvae," General and Comparative Endocrinology, Vol. 70, pp. 158-163 (1988).

91. Miwa, S., Yamano, K., and Inui, Y., "Thyroid Hormone Stimulates Gastric Development in Flounder Larvae during Metamorphosis," Journal of Experimental Zoology, Vol. 261, pp. 424-430 (1992).

92. Mohamed, J.S., Benninghoff, A.D., Holt, G.J., and Khan, I.A., "Developmental Expression of the G Protein-Coupled Receptor 54 and Three GnRH mRNAs in the Teleost Fish Cobia," Journal of Molecular Endocrinology, Vol. 38, pp.235-244 (2007).

93. Morley, J.E., "Neuroendocrine Control of Thyrotropin Secretion," Endocrine Reviews, Vol. 2, pp. 396-436 (1981).

94. Müller, A., "On the Development of Lampreys," Annals and Magazine of Natural History, Vol. 18, pp. 298301 (1856).

95. Murphy, K.G., "Kisspeptins: Regulators of Metastasis in the Hypothalamic-Pituitary-Gonadal Axis," Journal of Neuroendocrinol, Vol. 17, pp. 519-525 (2005). 
96. Murr, E. and Sklower, A., "Untersuchungen über die Inkretorischen Organe der Fische. I. Das Verhalten der Schilddrüse in der Metamorphose des Aales," Zeitschr Vergleichende Physiologie, Vol. 7, pp. 279-288 (1928).

97. Navarro, V.M., Castellano, J.M., Fernandez-Fernandez, R., Barreiro, M.L., Roa, J., Sanchez-Criado, J.E., Aguilar, E., Dieguez, C., Pinilla, L., and Tena-Sempere, M., "Developmental and Hormonally Regulated Messenger Ribonucleic Acid Expression of KiSS-1 and its Putative Receptor, GPR54, in Rat Hypothalamus and Potent Luteinizing Hormone-Releasing Activity of KiSS-1 Peptide," Endocrinology, Vol. 145, pp. 4565-74 (2004).

98. Nocillado, J.N., Levavi-Sivan, B., Carrick, F., Elizur, A., "Temporal Expression of G-Protein-Coupled Receptor 54 (GPR54), Gonadotropin-Releasing Hormones $(\mathrm{GnRH})$, and Dopamine Receptor D2 (drd2) in Pubertal Female Grey Mullet, Mugil cephalus," General and Comparative Endocrinology, Vol. 150, pp. 278-287 (2007).

99. Oehlmann, J. and Schulte-Oehlmann, U., "Endocrine Disruption in Invertebrates," Pure Applied Chemistry, Vol. 75, pp. 2207-2218 (2003).

100. Okada, N., Tanaka, M., and Tagawa, M., "Bone Development during Metamorphosis of the Japanese Flounder (Paralichthys olivaceus): Differential Responses to Thyroid Hormone," In Browman, H.I. and Skiftesvik, A.B., (eds), The Big Fish Bang: Proceedings of the $26^{\text {th }}$ Annual Larval Fish Conference, Institute of Marine Research, Bergen, Norway (2003).

101. Okuzawa, K., "Puberty in Teleosts," Fish Physiology and Biochemistry, Vol. 26, pp. 31-41 (2002).

102. Olivereau, M. and Olivereau, J., "Effects of $17 \alpha-$ Methyltestosterone on the Skin and Gonads of Freshwater Male Silver Eels," General and Comparative Endocrinology, Vol. 57, pp. 64-71 (1985).

103. Parhar, I.S., Ogawa, S., and Sakuma, Y., "Laser-Captured Single Digoxigenin-Labeled Neurons of Gonadotropin-Releasing Hormone Types Reveal a Novel G Protein-Coupled Receptor (Gpr54) during Maturation in Cichlid Fish," Endocrinology, Vol. 145, pp. 3613-3618 (2004).

104. Pasqualini, C., Vidal, B., Le Belle, N., Sbaihi, M., Weltzien, F.-A., Vernier, P., Zohar, Y., and Dufour, S., "Un Contre-Pouvoir au Contrôle de la Reproduction Par la GnRH chez Les Poisons Téléostéens: l'Inhibition Dopaminergique. Rôle Ancestral et Conservation Différentielle Chez les Vertébrés? Journal de la Société de Biologie, Vol. 198, pp. 61-67 (2004).

105. Peter, R.E. and Crim, L.W., "Hypothalamic Lesions of Goldfish: Effects on Gonadal Recrudescence and Gonadotropin Secretion," Aun Biol Anim Biochim Biophys, Vol. 18, pp. 819-823 (1978)

106. Peter, R.E. and Paulencu, C.R., "Involvement of the
Preoptic Region in the Gonadotropin Release-Inhibition in the Goldfish," Neuroendocrinology, Vol. 31, 133-141 (1980).

107. Peter, R.E., Crim, L.W., Goos, H.J.Th., and Crim, J.W., "Lesioning Studies on the Gravid Female Goldfish: Neuroendocrine Regulation of Ovulation," General and Comparative Endocrinology, Vol. 35, pp. 391-401 (1978).

108. Pompolo, S., Pereira, A., Estrada, K.M., and Clarke, I. J., "Colocalization of Kisspeptin and GonadotropinReleasing Hormone in the Ovine Brain," Endocrinology, Vol. 147, pp. 804-810 (2006).

109. Pradet-Balade, B., "Evolution de la Regulation de la Fonction Thyréotrope: Étude chez les Téléostéens," PhD Thesis University Paris XI (1998).

110. Prunet, P., Boeuf, G., Bolton, J.P., and Young, G., "Smoltification and Seawater Adaptation in Atlantic Salmon (Salmo salar): Plasma Prolactin, Growth Hormone and Thyroid Hormones," General and Comparative Endocrinology, Vol. 74, pp. 355-364 (1989).

111. Revel, F.G., Ansel, L., Klosen, P., Saboureau, M., Pévet, P., Mikkelsen, J.D., and Simmoneaux, V., "Kisspeptin: A Key Link to Seasonal Breeding," Reviews in Endocrine and Metabolic Disorders, Vol. 8, pp. 57-65 (2007).

112. Richman, N.H., de Diaz, S.T., Nishioka, R.S., and Bern, H.A., "Developmental Study of Coho Gill Functional Morphology and the Effects of Cortisol," Aquaculture, Vol. 45, pp. 386-387 (1985).

113. Robertson, O.G., "Production of Silvery Smolt Stage in Rainbow Trout by Intramuscular Injection of Mammalian Thyroid Extract and Thyrotropic Hormone," Journal of Experimental Zoology, Vol. 110, pp. 337-355 (1949).

114. Rohr, D.H., Lokman, P.M., Davie, P.S., and Young, G., "11-Ketotestosterone Induces Silvering-Related Changes in Immature Female Short-Finned Eels, Anguilla australis," Comparative Biochemistry and Physiology, Vol. 130A, pp. $701-714$ (2001).

115. Romeo, R.D., "Puberty: a Period of Both Organizational and Activational Effects of Steroid Hormones on Neurobehavioural Development," Journal of Neuroendocrinol, Vol. 15, pp. 1185-1192 (2003).

116. Rousseau, K. and Dufour, S., "Endocrinology of Migratory Fish Life Cycle in Special Environments: the Role of Metamorphoses," In Sébert, P., Onyango, D. W., and Kapoor, B.G. (eds), Fish Life in Special Environments, Science Publishers, UK, pp. 193-231 (2007). (in press)

117. Rousseau, K., Huang, Y.S., Le Belle, N., Vidal, B., Marchelidon, J., Epelbaum, J., and Dufour, S., "Longterm Inhibitory Effects of Somatostatin and InsulinLike Growth Factor 1 on Growth Hormone Release by Serum-Free Primary Culture of Pituitary Cells from 
European eel (Anguilla anguilla),"Neuroendocrinology, Vol. 67, pp. 301-309 (1998).

118. Saligaut, C., Linard, B., Breton, B., Anglade, I., Bailhache, T., Kah, O., and Jego, P., "Brain Aminergic Systems in Salmonids and Other Teleosts in Relation to Steroid Feedback and Gonadotropin Release," Aquaculture, Vol. 177, pp. 13-20 (1999).

119. Sbaihi, M., "Interaction des Stéroïdes Sexuels et du Cortisol dans le Contrôle de la Reproduction et du métabolisme Calcique Chez un Téléostéen Migrateur, l'anguille (Anguilla anguilla)," PhD Thesis University Paris VI (2001).

120. Sbaihi, M., Fouchereau-Peron, M., Meunier, F., Elie, P., Mayer, I., Burzawa-Gérard, E., Vidal, B., and Dufour, S., "Reproductive Biology of the Conger Eel from the South Coast of Brittany, France and Comparison with the European Eel," Journal of Fish Biology, Vol. 59, pp. 302-318 (2001).

121. Schreiber, A.M. and Specker, J.L., "Metamorphosis in the Summer Flounder, Paralichthys dentatus: Thyroidal Status Influences Gill Mitochondria-Rich Cells," General and Comparative Endocrinology, Vol. 117, pp. 238-250 (2000).

122. Seminara, S.B., "We All Remember our First Kiss: Kisspeptin and the Male Gonadal Axis," Journal of Clinical Endocrinology and Metabolism, Vol. 90, pp. 6738-6740 (2005).

123. Seminara, S.B., Messager, S., Chatzidaki, E.E., Thresher, R.R., Acierno, J.S. Jr., Shagoury, J.K., Bo-Abbas, Y., Kuohung, W., Schwinof, K.M., Hendrick, A.G., Zahn, D., Dixon, J., Kaiser, U.B., Slaugenhaupt, S.A., Gusella, J.F., O'Rahilly, S., Carlton, M.B., Crowley, W.F. Jr., Aparicio, S.A., and Colledge, W.H., "The GPR54 Gene as a Regulator of Puberty," The New England Journal of Medicine, Vol. 349, pp. 1614-27 (2003).

124. Shahab, M., Mastronardi, C., Seminara, S.B., Crowley, W.F., Ojeda, S.R., and Plant, T.M., "Increased Hypothalamic GPR54 Signaling: a Potential Mechanism for Initiation of Puberty in Primates," Proceedings of the National Academy of Science U.S.A., Vol. 102, pp. 2129-34 (2005).

125. Sheridan, M.A. and Kao, Y.-H., "Regulation of Metamorphosis-Associated Changes in the Lipid Metabolism of Selected Vertebrates," American Zoologist, Vol. 38, pp. 350-368 (1998).

126. Shi, Y.-B., Amphibian Metamorphosis, From Morphology to Molecular Biology. John Wiley, New York (1999).

127. Sisk, C.L. and Foster, D.L., "The Neural Basis of Puberty and Adolescence," Nature Neuroscience, Vol. 7, pp.1040-1047 (2004).

128. Sklower, A., "Die Bedeutung der Schilddruse Fur die Metamorphose des Aales und der Plattfische," Forsch Fortschr Dtsch Wiss, Vol. 6, pp. 435-436 (1930).
129. Smith, J.T., Clifton, D.K., and Steiner, R.A., "Regulation of the Neuroendocrine Reproductive Axis by Kisspeptin-GPR54 Signaling," Reproduction, Vol. 131, pp. 623-630 (2006).

130. Smith, J.T., Dungan, H.M., Stoll, E.A., Gottsch, M.L., Braun, R.E., Eacker, S.M., Clifton, D.K., and Steiner, R.A., "Differential Regulation of Kiss-1 mRNA Expression by Sex Steroids in the Brain of the Male Mouse," Endocrinology, Vol. 146, pp. 2976-2984 (2005).

131. Soffientino, B. and Specker, J.L., "Metamorphosis of Summer Flounder, Paralichthys dentatus: Cell Proliferation and Differentiation of the Gastric Mucosa and Developmental Effects of Altered Thyroidal Status," Journal of Experimental Zoology, Vol. 290, pp. 31-40 (2001).

132. Solbakken, J.S., Norberg, B., Watanabe, K., and Pittman, K., "Thyroxine as a Mediator of Metamorphosis of Atlantic Halibut, Hippoglossus hippoglossus," Environmental Biology of Fishes, Vol. 1-2, pp. 53-65 (1999).

133. Specker, J.L., "Interrenal Function and Smoltification," Aquaculture, Vol. 28, pp. 59-66 (1982).

134. Sterba, G. and Schneider, J., "Zur Wirkung von Kalliumperchlorat (KClO4) auf Ammocoeten," Naturwissenschaften, Vol. 48, pp. 485-486 (1961).

135. Sullivan, C.V., Darling, D.S., and Dickhoff, W.W., "Effects of Triiodothyronine and Propylthiouracil on Thyroid Function and Smoltification of Coho Salmon (Oncorhynhcus kisutch)," Fish Physiology and Biochemistry, Vol. 4, pp. 121-135 (1987).

136. Suzuki, S., "Induction of Metamorphosis and Thyroid Function in the Larval Lamprey," In Mederios-Neto, G. and Gaitan, E. (eds), Frontiers in Thyroidology, Plenum, New York, Vol. 1, pp. 667-670 (1986).

137. Sweeting, R.M. and McKeown, B.A., "Changes in Plasma Growth Hormone and Various Metabolic Factors during Smoltification of Coho Salmon, Oncorhynchus kisutch," Aquaculture, Vol. 82, pp. 279295 (1989).

138. Sweeting, R.M., Wagner, G.F., and McKeown, B.A., "Changes in Plasma Glucose, Amino Acid, Nitrogen and Growth Hormone during Smoltification and Seawater Adaptation in Coho Salmon, Oncorhynchus kisutch," Aquaculture, Vol. 45, pp. 185-197 (1985).

139. Tagawa, M., Miwa, S., Inui, Y., de Jesus, E.G., and Hirano, T., "Changes in Thyroid Hormone Concentrations during Early Development and Metamorphosis of the Flounder, Paralichthys olivaceus," Zoological science, Vol. 7, pp. 93-96 (1990).

140. Tata, J.R., "Hormonal Interplay and Thyroid Hormone Receptor Expression during Amphibian Metamorphosis," In Gilbert, L.I., Tata, J.R., and Atkinson, B.G. (eds), Metamorphosis. Postembryonic Reprogramming of Gene Expression in Amphibian and Insect Cells, 
Academic Press, San Diego (1996).

141. Tata, J.R., Hormonal Signalling and Postembryonic Development, Springer, Berlin (1998).

142. Tata, J.R., "Amphibian Metamorphosis as a Model for the Developmental Actions of Thyroid Hormone," Molecular and Cellular Endocrinology, Vol. 246, pp. 10-20 (2006).

143. Thiéry, J.C., Chemineau, P., Hernandez, X., Migaud, M., and Malpaux, B., "Neuroendocrine Interactions and Seasonality," Domestic Animal Endocrinology, Vol. 23, pp. 87-100 (2002).

144. Thompson, E.L., Patterson, M., Murphy, K.G., Smith, K.L., Dhillo, W.S., Todd, J.F., Ghatei, M.A., and Bloom, S.R., "Central and Peripheral Administration of Kisspeptin-10 Stimulates the Hypothalamic-PituitaryGonadal Axis," Journal of Neuroendocrinol, Vol. 16, pp. 850-8 (2004).

145. Van Asselt, L.A., Goos, H.J., Smit-van Dijk, W., Speetjens, P.A.M., Van Oordt, P.G., "Evidence for the Involvement of D2 Receptors in the Dopaminergic Inhibition of Gonadotropin Release in the African Catfish, Clarias gariepinus," Aquaculture, Vol. 72, pp. 369-378 (1988).

146. Van der Kraak, G., Donaldson, E.M., and Chang, J.P., Dopamine Involvement in the Regulation of Gonadotropin Release in Coho Salmon," Canadian Journal of Zoology, Vol. 64, pp. 1245-1248 (1986).

147. Veldhuis, J.D., Roemmich, J.N., Richmond, E.J., and Bowers, C.Y., "Somatotropic and Gonadotropic Axes Linkages in Infancy, Childhood and the Puberty-Adult Transition," Endocrine Reviews, Vol. 27, pp. 101-140 (2006).

148. Vidal, B., Pasqualini, C., Le Belle, N., Holland, M.C., Sbaihi, M., Vernier, P., Zohar, Y., and Dufour, S., "Dopamine Inhibits Luteinizing Hormone Synthesis and Release in the Juvenile European Eel: a Neuroendocrine Lock for the Onset of Puberty," Biology Reproduction, 71, pp. 1491-500 (2004).

149. Vilter, V., "Action de la Thyroxine Sur la Metamorphose Larvaire de l'Anguille," Comptes Rendus des Seances de la Societe de Biologie et des Ses Filiales, Vol. 140, pp. 783-785 (1946).

150. Virtanen, E. and Soivio, A., "The Patterns of T3, T4, Cortisol and $\mathrm{Na}^{+}-\mathrm{K}^{+}$ATPase during Smoltification of Hatchery Reared Salmo salar and Comparison with wild Smolts," Aquaculture, Vol. 45, pp. 97-109 (1985).

151. White, B.A. and Nicoll, C.S., "Hormonal Control of Amphibian Metamorphosis," In Gilvert, L.I. and Frieden, E. (eds), Metamorphosis, Plenum Press: New York, pp. 363-396 (1981).
152. Wright, G.M. and Youson, J.H., "Serum Thyroxine Concentrations in Larval and Metamorphosing Anadromous Sea Lamprey, Petromyzon marinus L," Journal of Experimental Zoology, Vol. 202, pp. 27-32 (1977).

153. Yamano, K., Tagawa, M., de Jesus, E.G., Hirano, T., Miwa, S., and Inui, Y., "Changes in Whole Body Concentrations of Thyroid Hormones and Cortisol in Metamorphosing Conger Eel," Journal of Comparative Physiology B, Vol. 161, pp. 371-375 (1991).

154. Yaron, Z., Gur, G., Melamed, P., Rosenfeld, H., Elizur, A., and Levavi-Sivan, B., "Regulation of Fish Gonadotropins," International Review of Cytology, Vol. 225, pp. 131-185 (2003).

155. Young, G., Björnsson, B.T., Prunet, P., Lin, R.J., and Bern, H.A., "Smoltification and Seawater Adaptation in Coho Salmon (Oncorhynchus kisutch): Plasma Prolactin, Growth Hormone, Thyroid Hormone and Cortisol," General and Comparative Endocrinology, Vol. 74, pp. 335-345 (1989).

156. Youson, J.H., "The Morphology and Physiology of Lamprey Metamorphosis," Canadian Journal of Fisheries and Aquatic Sciences, Vol.37, pp. 687-710 (1980).

157. Youson, J.H., "First Metamorphosis," In Hoar, W.S. and Randall, D.J. (eds), Fish Physiology, Vol. XI, Physiology of Developing Fish, Part B, Viviparity and Posthatching Juveniles, Academic Press, San Diego, pp 135-196 (1988).

158. Youson, J.H., "Is Lamprey Metamorphosis Regulated by Thyroid Hormones?" American Zoologist, Vol. 37, pp. 441-460 (1997).

159. Youson, J.H., Plisetskaya, E.M., and Leatherland, J.F., "Concentrations of Insulin and Thyroid Hormones in Serum of Landlocked Sea Lampreys (Petromyzon marinus) of Three Larval Year Classes, Larvae Exposed to Two Temperature Regimes, and Both during and after Metamorphosis," General and Comparative Endocrinology, Vol.94, pp. 294-304 (1994).

160. Youson, J.H., Manzon, R.G., Peck, B.J., and Holmes, J. A., "Effects of Exogenous Thyroxine (T4) and Triiodothyronine (T3) on Spontaneous Metamorphosis and Serum T4 and T3 Levels in Immediately Premetamorphic Sea Lampreys, Petromyzon marinus," Journal of Experimental Zoology, Vol. 279, pp. 145-155 (1997).

161. Zohar, Y., Harel, M., Hassin, S., and Tandler, A., "Broodstock Management and Manipulation of Spawning in the Gilthead Seabream, Sparus Aurata," In Bromage, N. and Roberts, R.J. (eds), Broodstock Management and Egg and Larval Quality, Blackwell Scientific Press, London, pp. 94-117. 